\title{
Professional training in physiotherapy: primary care practices
}

\author{
Formação profissional em fisioterapia: práticas realizadas na \\ atenção básica
}

\author{
Luciana Tavares Ferreira (iD [a], Fátima Ferretti ${ }^{[1]}$, Carla Rosane Paz Arruda Teo [i] \\ Hedioneia Maria Foletto Pivetta [i] $[\mathrm{b}] *$
}

[a] Universidade Comunitária da Região de Chapecó (UNOCHAPECÓ), Chapecó, SC, Brazil

[b] Universidade Federal de Santa Maria (UFSM), Santa Maria, RS, Brazil

\begin{abstract}
Introduction: Professional training in physiotherapy still focuses primarily on rehabilitation; however, there is a need to ensure that these professionals are also equipped to work in primary care (PC), since it is the gateway to the healthcare system. Objective: Identify practices carried out in PC by undergraduate physiotherapy courses in Santa Catarina state, Brazil, from the perspective of professors. Method: Qualitative study with a multiple-case design. All eight undergraduate physiotherapy courses available in the state were included as cases in this study. Five physiotherapy professors also took part as key informants (KIs) Data were collected by document analysis of course pedagogical projects (CPPs) and a semi-structured interview regarding training practices conducted in primary care (PC) settings. Data were analyzed using thematic analysis. Results: Based on content analysis of the interviews, practices carried out in PC by the different courses include territorialization; specific group activities; home health care/home visits; postural education in school settings; interdisciplinary and multiprofessional experiences; interviews; waiting room
\end{abstract}

*LTF: Master's Student, e-mail: luciana.ferreira@unochapeco.edu.br

FF: PhD, e-mail: ferrettifisio@yahoo.com.br

CRPAT: PhD, e-mail: carlateo@unochapeco.edu.br

HMFP: PhD, e-mail: hedioneia@yahoo.com.br 
activities; combined consultations and singular therapeutic projects. Conclusion: practices performed in primary care facilities by undergraduate physiotherapy courses in Santa Catarina state (SC), Brazil, are aimed at meeting primary care needs; however, teaching-service-community integration is essential in order to diversify these PC experiences throughout the training process and expand interdisciplinary and multiprofessional activities.

Keywords: Human Resources Development. Physical Therapy Specialty. Primary Health Care.

\section{Resumo}

Introdução: A formação profissional em Fisioterapia ainda se dá muito centrada em práticas reabilitadoras, contudo, observa-se a necessidade de garantir no processo formativo práticas desenvolvidas na Atenção Básica $(A B)$, visto que esta é a principal porta de entrada para o sistema de saúde. Objetivo: Desvelar as práticas realizadas na AB pelos cursos de graduação em Fisioterapia no estado de SC, segundo o olhar dos docentes. Método: Estudo de abordagem qualitativa, tendo como método o estudo de casos múltiplos. Oito cursos de graduação em Fisioterapia presentes no estado catarinense, constituíram-se nos casos desta pesquisa. Participaram do estudo cinco docentes fisioterapeutas como Informantes-Chave (IC). A coleta de dados se deu por meio de análise documental dos Projetos Pedagógicos dos Cursos (PPCs) e de entrevista semiestruturada quanto as práticas realizadas no contexto da $A B$. A análise de dados se deu mediante análise de conteúdo temática. Resultados: A partir da análise de conteúdo das entrevistas, entre as práticas realizadas na AB pelos cursos, estão a territorialização; ações em grupos específicos; atenção domiciliar/visita domiciliar; educação postural no contexto escolar; vivências interdisciplinares e multiprofissionais; entrevista; ações em sala de espera; consultas compartilhadas e projeto terapêutico singular. Conclusão: As práticas realizadas pelos cursos de graduação em Fisioterapia no estado de SC buscam atender as demandas da atenção básica, no entanto, há que se estabelecer a integração ensino-serviço-comunidade, a fim de potencializar a diversificação dessas vivências na AB ao longo do processo formativo, ainda ampliar as atividades interdisciplinares e multiprofissionais.

Palavras-chave: Capacitação de Recursos Humanos. Curso de Fisioterapia. Atenção Primária à Saúde.

\section{Introduction}

Since the creation and implementation of the Brazilian National Health System (SUS), professional practices and work organization have undergone a number of changes, prompting the need to streamline tasks performed and redefine responsibilities between healthcare professionals and services [1].

The training process for healthcare professionals needs to be redefined to ensure that students acquire the necessary skills to meet the needs of the new healthcare model, which prioritizes multiprofessional teams, interdisciplinary activities and better integrated teams, considering all human dimensions (biological, psychological, social, cultural, ethical and political, among others) [2].

As in other healthcare professions, physiotherapy remains focused on rehabilitation [3]. However, the current health scenario in the country and SUS highlights the need to ensure that training includes primary care (PC) activities, since it is the gateway to the healthcare system, coordinating care and organizing Health Care Network (RAS) actions and services [4].

In recent years, course proposals have suggested placing students in public health services to experience the real health needs of the population first hand. National curriculum guidelines (NCD) for undergraduate physiotherapy courses stipulate that practical activities should gradually increase in complexity during training, progressing from simple observation to supervised activities [5].

Additionally, primary care settings are recognized for their learning potential in professional training, connecting users' homes, the local community and RAS [6]. Diversifying these settings is also important because it favors comprehensive professional training, allowing 
the construction and appropriation of competences by sharing, exchanging and enhancing knowledge [7-10].

In light of the above, this study aimed to identify practices carried out in PC by undergraduate physiotherapy courses in Santa Catarina state, Brazil, from the perspective of teachers.

\section{Method}

This qualitative multiple-case study [11] forms part of an analysis based on the dissertation entitled "Professional training in physiotherapy in Santa Catarina state: emphasis on primary care" and was conducted in Santa Catarina state (SC) with professors from undergraduate physiotherapy courses. Courses were selected based on a report available on the Sistema e-MEC database of the Ministry of Education and Culture, which listed 24 undergraduate physiotherapy courses in the state in July 2017. Selection criteria were in-person courses; comprehensive curricular framework; course pedagogical project (CPP) available in the public domain or by email on request. Based on these criteria, eight active courses in the state were identified and selected.

Initial document analysis sought to provide researchers with information on the forecasting and organization of practical activities by the courses, in order to facilitate the semistructured interviews with key informants (KIs).

The KIs were chosen after initial contact with course coordinators who identified faculty members that met the following selection criteria: professor in the physiotherapy course with extensive experience in PC and a degree in physical therapy. Based on the recommendations of course coordinators, the professors were contacted and officially invited to take part in the study.

Seven professors were recommended, but one had a degree in medicine, and another was unavailable for the interview, leaving five professors who participated in this investigation.

The semistructured interviews were conducted individually with each KI via a video call, using a script with guiding questions on the courses that included activities performed in PC, how these were organized and in what scenarios they were developed within the PC setting in order to provide professional training to physical therapy students that included this level of care.

The interviews were conducted from October to December 2017. The KIs were identified using letters followed by numbers in order to keep their identity confidential. Recordings and transcriptions of their statements were saved in digital files and sent to the individual professors by email for approval.

The empirical data of the interviews was evaluated by thematic analysis, as proposed by Minayo [12], consisting of three stages: pre-analysis, exploring the material, and treatment and interpretation of the results. The study followed the ethical principles for research with human beings, in line with the standards and guidelines of Resolution 466/CNS/2012 of the Ministry of Health's National Health Council (CNS/MS). It was approved by the institutional Research Ethics Committee, under protocol 2.323.022.

\section{Results}

Three of the participating professors were women and two men, with an average age of $41.2 \pm 8.6$ years and average teaching time in higher education of $11.6 \pm 8.5$ years. With respect to their academic titles, three held master's degrees (in Health Management; Biosciences and Health; and Collective Health) and two PhDs (in Collective Health and Health Sciences).

Thematic analysis of the empirical material of the interviews on activities performed in PC by physiotherapy courses from the perspective of the KIs produced the following categories: territorialization; specific group activities; home health care/home visits; postural education in school settings; interdisciplinary and multiprofessional experiences; interviews; waiting room activities; combined consultations and singular therapeutic projects.

\section{Discussion}

Among the activities performed out in PC by the selected physiotherapy courses in SC state, the KIs identified territorialization as a practice in initial courses of the different programs. Although proposed as an introduction to PC, it was not mentioned in relation to internships, as indicated in the statements by professors below:

In the first semester of the Collective Health course [...], students study the structure and work process of PC, 
the team, territory, and profile of the community covered [...]. Along these same lines, there is an Ethics and Citizenship course in the second semester that has some content on PC, more specifically it addresses the issue of territorialization [...]. Professors discuss the subject with students, who then apply this to basic health units (BHUs) [...] (D2).

We cover territorialization in Primary Care I, in the 4th semester of the physiotherapy course, and students compile a conceptual map addressing the geographical issues, number of people in the neighborhood, risk areas, and other data... (D4).

According to the National Primary Healthcare Policy (PNAB), territorialization involves geographical analysis of the region of a population enrolled in the program in order to map the health needs of the community and plan the healthcare initiatives to be implemented. It is important to note that, according to SUS and RAS guidelines, territorialization should be operationalized within PC [13].

Based on the recently updated PNAB, territorialization is performed in PC by healthcare professionals as a form of organizing and structuring the Health Care Network (RAS), promoting cohesion between services and effective care in the SUS [13]. It is important for undergraduate physiotherapy students working in PC, either as part of Family Health Strategy (FHS) or Family Health Center Support (NASF) teams, to participate in these activities in order to identify priorities for physiotherapy care and plan the necessary strategies [14]. Acknowledging territorialization as a physiotherapy work process and therefore a practice that should be developed in PC during student training fosters the formation of professionals equipped for health surveillance. It also helps students to better understand the complexity of the healthcare system and how it functions in a unique setting.

Another practice highlighted by the professors interviewed as being performed at the beginning of courses and during internships were specific group activities, aimed at developing health promotion and education as well as preventing disease and injury. Group activities involve bringing people with a common goal together in order to deconstruct and create new meanings for a specific them, such as the elderly, hypertensive patients, and postural education, among others [15].

According to the professors' statements, specific group activities are organized and proposed for all stages of life and different populations, including children, adolescents, women, workers and the elderly, as demonstrated below:

At the moment, the workload of a student internship [...] is divided between several different BHUs in the municipality [...], with activities in mother and baby groups, health education initiatives [...], accompanying other physical therapists and nutritionists, sometimes as part of joint initiatives such as walking and nutritional guidance groups [...]. We also have groups for the elderly, women, new mothers, and pregnant women who come for a prenatal checkup; before their appointment there is an opportunity to talk to these patients, which healthcare professionals cannot always do, so the students step in (D4).

Courses from the fifth semester onwards include Physiotherapy Practices I, II, III, IV, Vand VI, which continue to the 10th semester and involve group activities at BHUs, such as pregnancy support and occupational health groups (D5).

Authors such as Menezes and Avelino [16] emphasize that group interventions in PC "[...] promote collective problematization and discussion, ensuring ongoing learning". According to the PNAB, primary care professionals are responsible for implementing group-based educational and health promotion activities aimed at fostering increased self-esteem, joint responsibility and bonding. This strategy also helps strengthen the social support network for people coping with different healthcare needs [13].

In this multiple case study, the adoption of specific group activities by the courses studied can be considered an advance, since it enables students to perform health promotion and education and disease prevention activities that include group rehabilitation, thereby incorporating the different forms of working in PC.

Home health care (HHC) was also mentioned by interviewees as one of the most frequently performed practices in PC. At this point, it is important to note what HHC and Home visits (HV) entail. In accordance with Ordinance 825 of April 25, 2016, within the SUS, home health care "[...] forms part of the Health Care Network (RAS) and consists of a set of disease prevention and treatment, rehabilitation, palliative care and health promotion services provided at patients' homes to guarantee continuity of care [...]" [17].

As such, HHC is recommended for users with controlled health problems who are temporarily or 
permanently bedridden or confined to their homes and need to be monitored by specific healthcare teams for rehabilitation, preventing aggravation or palliative care [17]. In addition to rehabilitation, $\mathrm{HHC}$ also incorporates educational activities as part of an interdisciplinary approach with the healthcare team, user and family [10]. It is an important practice in the context of $\mathrm{PC}$, capable of equipping physiotherapy students with the knowledge and attitudes they need to work in a team and solve health problems alongside other healthcare areas during their training.

Home visits (HVs) are when healthcare professionals travel to users' homes to identify their health needs and provide the necessary care considering the family unit as a whole [18].

At times, there is some confusion on the part of professionals regarding the different activities performed by physiotherapists in these home-based modalities. Home health care can be provided in an HV, but in the latter there is no individual physiotherapy. Home visits involve a broader view of the family and their lifestyle within the domestic setting, where the healthcare team focuses on strengthening ties and monitoring the health of the family $[18,13]$.

As a tool in the learning process, HVs were identified in a study by Medeiros, Pivetta and Mayer [19] as an instrument to reflect on and transform how healthcare is viewed and provided. The authors emphasize that experiencing these family environments expanded the students' concept of health, prompting reflection and fostering conduct based on humanized care through the bond developed. This contributes to co-responsibility in the care process between the healthcare professional/ student and users and gives new meaning to the learning process.

One interviewee provided a detailed description of HVs during internships, highlighting their importance as a multidisciplinary team practice that provides care by identifying the health problems in a specific family setting.

We do home visits during internships, often as part of a team. It's not unusual to have a doctor present, as well as medical students and a nurse or community health agent. We assess the family to identify their needs, provide guidance and refer them to specialized services when necessary (D2).

Other KIs emphasized that home visits are performed more frequently during internships. Studies have shown a latent demand for rehabilitation in PC and as such, undergraduate physiotherapy students and physical therapists are expected to meet this demand during home visits as part of $\mathrm{HHC}$, that is, tertiary care [20-22]. Several statements demonstrate this:

Activities during internships [...] are largely home visits. In fact, most consultations are in the form of home visits, typically not for prevention and promotion, but rehabilitation (D3).

The healthcare teams often want us to provide individual care, but that's not the level of care we're supposed to be providing! It's difficult for healthcare professionals to understand that students are not physiotherapists, and that at this point in their internship they are there at a primary care level, so the issue of rehabilitation is inevitable (D4).

Another practice that brings students closer to $\mathrm{PC}$ is postural education in school settings, affiliated with the School Health Program (PSE) [23]. This program aims to providing students with comprehensive training in the primary care network and requires interdisciplinary action and collaboration between education and health. Thus, postural education is one of the practices carried out during physiotherapy training, since, according to Bispo Jr [3], "postural education in schools should be an ongoing activity between the health and education sectors, with prominent participation by teachers, promoting the school setting and the children's universe as the preferred location for this practice."

In this regard, a positive aspect cited by the professors interviewed is that postural education during physiotherapy training is not only performed during internships, but also forms part of courses and outreach projects, reinforcing the role of physical therapists as health educators. The following two accounts by KIs demonstrate this viewpoint:

Preventive physiotherapy addresses health issues at school and provides guidance on posture... (D2).

The university runs a project, not specific to the physiotherapy program but integrated with other undergraduate courses and supervised by different professors, in which students give talks at schools and the physiotherapy program is responsible for the postural guidance provided by students in all stages of the project (D3). 
Different studies have investigated the effects of a Postural Education Program (PEP) carried out by physiotherapy courses in schools for a variety of age ranges and observed changes in behavior, better theoretical knowledge and improved posture in activities of daily living among the children and adolescents. The program was also well accepted and favorably assessed by both the teachers and students at the schools involved [24-26]. Another study that assessed the perspective of students and professors in healthcare courses regarding the inclusion and performance of physical therapists in PC reported that interviewees identified health education as a vital tool, particularly for postural groups [10]. The school served as a learning scenario that provided the opportunity for interaction with educators and children with different needs, favoring discussion regarding intersectoral action in the training process and prompting collaboration between the education and health sectors.

In addition to postural education, school settings provide a number of other possibilities that go beyond guidance and incorporate ergonomic adjustments by the different students in their interaction with the environment, as well as other elements that could be addressed in the form of practical experiences.

In regard to practices that favor multidisciplinary teamwork, three professors highlighted interdisciplinary and multiprofessional experiences as activities performed in PC. These experiences are a vital part of training for physiotherapists and other healthcare professionals since teamwork is key to providing effective PC and comprehensive health care [13].

Interdisciplinary and multiprofessional experiences are performed as part of a course and have a practical and theoretical component. In practice, students from different programs are placed in BHUs as their first contact with primary care, not as physiotherapists but in the Family Health Strategy (FHS) program, which I feel is very important (D4).

For us, these are already well-established activities... we take part alongside other students from courses in medicine, nursing, dentistry, psychology and physical education, in a multiprofessional team... It's really interesting because in the same semester students are working in clinical practice and PC. In clinical practice the focus is on physiotherapy, but when students work in PC, they have the opportunity to experience multiprofessional and interdisciplinary teams (D2).
There were few opportunities for multiprofessional and interdisciplinary activities in the courses analyzed here. Several studies have highlighted the difficulties experienced by healthcare professionals in interdisciplinary work, "[...] for fear of invading others' field of knowledge" [27]. This occurs when the training process does not foster collaboration between different higher education institutions, courses, professors and students from the field of health and other areas of knowledge. In this regard, Peduzzi [28] states that, in Brazil, health education and training is predominantly 'uniprofessional', that is, interactions between students from a same professional field are limited and occur in isolation, an aspect that needs to improve. This was addressed by one of the interviewees, as follows:

Students have emphasized the difficulty of teamwork; in other words, they've reported a lack of interdisciplinary work at healthcare units and in fact, there are discussions as to the possibility of addressing this in a thesis or something similar. (D3).

Additionally, in terms of reshaping physiotherapy training in accordance with SUS prerogatives and based on primary care, course pedagogical projects (CPPs) should stipulate that courses and educational institutions provide training that includes collective health, integrality of care and interdisciplinary work $[29,30]$.

It is important to underscore the scarcity of practical PC activities among the different health courses, making it difficult to break from the traditional training model since multiprofessional and interdisciplinary work is the cornerstone of the SUS. It is a vital part of professional training and favors more comprehensive development, considering all the human dimensions (biological, social, cultural, psychological, ethical and political). This enhances integrated action and enables a broader understanding of the concept of health, consolidating the relationships between those involved in the process [31].

Practical experiences in multiprofessional, interdisciplinary activities are key elements in expanding and extrapolating PC practices. They encourage students to reflect on the strengths and weaknesses of working in a team based on their own knowledge, since it is through dialogue and the reciprocal exchange of knowledge and experiences that they perceive their own role.

Several pedagogical strategies were used to allow students to experience firsthand the work of healthcare teams in PC. Two courses proposed using interviews as 
a data collection instrument to identify the structural conditions, values, standards and symbols of a particular topic under study [12].

In this activity, the work processes of primary care staff were analyzed through dialogue and the information recorded by physiotherapy students, as explained by the KIs below:

In collective health [when addressing SUS and FSH operations] students photograph, film and compile a script for interviewing healthcare teams (D3).

In the Primary Care I course of the physiotherapy program [...] we address the work of physical therapists in PC and talk about Family Health Support Centers (NASFs); an interview was proposed with physiotherapists who work in primary care in some capacity, not necessarily at NASFs, to find out how they were trained for their role, their work process, and demonstrate the relationship with academic training (D4).

This is an interesting strategy for students to recognize and understand the work process of healthcare professionals within PC. In order to enhance this strategy and promote greater approximation between educational institutions and health services, as stipulated by the CPPs of undergraduate health programs [13], it is important to provide feedback to healthcare professionals regarding the information collected by students. This can be achieved by participating in team meetings or scheduling meetings with the healthcare team "[...] not only to certify SUS staff, but develop the healthcare system itself by reflecting on the reality of the services and what changes are needed, with a view to improving management and the care provided".

It is important to note that the final three PC practices described below were only mentioned by one KI, but for two different courses: Waiting room activities were only mentioned once. The waiting room is a dynamic space that provides an opportunity for interventions that contribute to collective care [32].

We also carry out health education initiatives with patients in the waiting room by discussing certain topics or reinforcing national health campaigns, during prostate cancer awareness month, for example. It's also an opportunity to raise awareness about different group activities and invite patients to take part (D4).
The waiting room is a strategic space that can be used to enhance health education initiatives, for example. Santos et al. [33] described the experiences of student monitors from a nursing program in the PETSaúde program who interacted with pregnant women in waiting rooms. The authors found that these spaces provided an opportunity to bond, share experiences and exchange technical and scientific knowledge.

As such, it is valid to assume that the different activities proposed for waiting rooms in healthcare units would include students from other fields who are also undertaking practical experience or internships in PC, promoting multiprofessional and interdisciplinary work during the training process.

Combined consultations were also mentioned as an opportunity for teamwork during professional training. In the practical situation cited by the KI, the combined consultation was carried out with a nurse and addressed women's health, as described below:

Combined consultations for pre and postnatal care help monitor the patient not only in terms of disease, but also the pregnancy itself, providing pertinent guidance and preparing her for delivery, as well as identifying other needs such as pelvic floor issues, urine leakage and other complaints. So when the nurse schedules a pap smear, we can also participate with health education and promotion initiatives... (D2).

Combined consultations are also covered by the PNAB but contextualized as one of the most common practices for NASF teams, bringing support teams closer to the user and encouraging healthcare professionals to discuss cases among themselves [34].

Since it contributes to the creation of interdisciplinary activities, this practice is an important strategy for inclusion in physiotherapy and other health-related courses as practical PC experience, whether as part of internships or not. According to Castro et al. [35], "interdisciplinary work is an important tool in improving healthcare conditions, tackling the fragmentation of knowledge and, consequently, the division of isolated specialties".

In the CPPs of undergraduate health courses [13], combined consultations form part of the professional training framework based on teamwork, which "[...] should be viewed as going beyond different subjects occupying the same space." Including this practice in 
formal physiotherapy training is a good strategy to bring students closer to the reality of healthcare services, exploring the different contributions of each professional; however, only one professor from the courses studied mentioned this activity. Thus, mechanisms must be created to provide students with different PC experiences.

Finally, singular therapeutic projects were also cited by one KI. Similar to combined consultations, singular therapeutic projects (PTS) are a health care strategy that, according to Primary Care Manual [34], "are a set of combined therapeutic proposals for an individual or group resulting from interdisciplinary team discussions, which can be supported by the NASF team".

We discuss the treatment plan for a particular family and what type of care to provide in specific situations, such as biological or social risks or more technical needs, but primarily, we provide guidance on how to proceed regarding the family's health needs... [...] the singular therapeutic project is discussed with the entire team, which includes not only FHS personnel but the students from other courses that are doing internships (D2).

Based on the statement above, PTS are devised during the physiotherapy internship within a PC setting in conjunction with students from other health-related courses, making it a key strategy that strengthens interdisciplinary activities in healthcare services.

In general, it is important to prioritize teamworkoriented practices that enable the extrapolation and expansion of knowledge regarding the health-disease process when training physiotherapists to work in primary care, such as interdisciplinary and multiprofessional experiences, combined consultations and PTS.

In order to ensure that the training provided allows students to develop the necessary skills to work in interdisciplinary multiprofessional teams in primary care, practical activities should gradually increase in complexity, as stipulated in national curriculum guidelines (NCD), so that students learn to work with other professionals as well as students from other fields.

To that end, diverse practical scenarios are needed, requiring students to be present and involved in the communities and regions to ensure a better understanding of theoretical frameworks. This also allows them to expand on what they have learned in theory by experiencing it in practice, with all its complexities and demands, as well as the different means of organizing and managing the various services. Coming into contact with the realities of health care enables students to explore the context and move beyond simple theory.

There are still a number of challenges to improving physiotherapy training and equipping physiotherapists to work in primary care, understanding the structure, functioning and work processes at this care level.

\section{Conclusion}

The physiotherapy courses analyzed here provide teaching and learning experiences in a primary care context. With respect to the activities carried out by the courses, the most cited were territorialization, specific group activities and home health care/home visits. Other less common practices reported by some KIs were postural education in schools, interdisciplinary and multiprofessional experiences, interviewees, waiting room activities, combined consultations and singular therapeutic projects. Additionally, courses taught before internships include practices that allow students to experience different PC scenarios, representing a significant advance in terms of bringing them closer to this care level.

Despite this progress, both theoretical and practical content needs to be expanded and learning scenarios diversified. In order to promote these changes, greater teaching-service interaction is needed, making it important to establish coherent strategies for collaborative planning between educational institutions and healthcare services. This cooperation between institutions and services could enhance teaching practices for the SUS/PC setting, equipping students to work in teams and with other sectors of the community.

One of the study limitations is the failure to include students, making it important to conduct further research with this group to determine how they assess and perceive activities performed in PC during their training.

Professional physiotherapy training has progressed and a number of changes have been made; however, there are still many challenges to ensure that the training provided equips physical therapists to work in primary care, understanding and acting in accordance with the structure, functioning and work processes of this care level. 


\section{References}

1. Brasil. Ministério da Saúde. Secretaria de Gestão do Trabalho e da Educação na Saúde. Departamento de Gestão da Educação na Saúde. AprenderSUS: o SUS e os curos de graduação da área da saúde. Brasília: Ministério da Saúde; 2004. 20 p.

2. Castro SS, Silva YHG, Leite CF, Bollela VR. O processo saúde-doença e o modelo biopsicossocial entre supervisores de um curso de fisioterapia: estudo qualitativo em uma universidade pública. Cad Edu Saude e Fis. 2015;2(3):23-38.

3. Bispo JJP. Fisioterapia e saúde coletiva: Desafios e novas responsabilidades profissionais. Cienc Saude Coletiva. 2010;15(Suppl1):1627-36.

4. Brasil. Portaria n. 2.436, de 21 setembro de 2017. Aprova a Política Nacional de Atenção Básica, estabelecendo a revisão de diretrizes para a organização da Atenção Básica, no âmbito do Sistema Único de Saúde (SUS). Brasília: Diário oficial da União; 2017 Sep 22.

5. Brasil. Ministério da Educação. Conselho Nacional de Educação. Câmara de Educação Superior. Resolução CNE/CES n. 4, de 19 de fevereiro de 2002. Institui Diretrizes Curriculares Nacionais do Curso de Graduação em Fisioterapia. Brasília: Diário Oficial da União; 2002 Mar 4.

6. Delai KD, Wisniewski MSW. Inserção do fisioterapeuta no Programa Saúde da Família. Cienc Saude Coletiva. 2011;16(Suppl 1):1515-23.

7. Rocha VM, Caldas MAJ, Araújo FRO, Ragazzon CAP, Santos MLM, Batiston AP. As diretrizes curriculares e as mudanças na formação de profissionais fisioterapeutas (Abenfisio). Fisioter Bras. 2010;11(5):4-8.

8. Fujisawa DS, Araújo FRO, Rocha VM, Santos MLM. Padrão de qualidade dos cursos de graduação em fisioterapia no contexto do Sistema Nacional de Avaliação da Educação Superior - SINAES. Fisioter Bras. 2012;13(4):5-11.

9. Teixeira RC. Aderência dos cursos de Fisioterapia da região Norte às Diretrizes Curriculares Nacionais. Fisioter Mov. 2012;25(1):47-54.

10. Souza MC, Rocha AA, Souza JN. Fisioterapia e sua práxis na atenção básica. RPF. 2014;4(1):26-34.
11. Yin RK. Estudo de Caso: planejamento e métodos. Porto Alegre: Bookman; 2015.

12. Minayo MCS. O desafio do conhecimento: pesquisa qualitativa em saúde. São Paulo: Hucitec; 2014.

13. Brasil. Ministério da Saúde. Resolução CNS n. 569, de 8 de dezembro de 2017. Aprovar o Parecer Técnico n. $300 / 2017$, que apresenta princípios gerais a serem incorporados nas DCN de todos os cursos de graduação da área da saúde. Brasília: Diário Oficial da União; 2018 Feb 26.

14. Oki MM, Préve AD, Pereira J. A atuação do fisioterapeuta na atenção básica no município de Florianópolis (SC). In: Pereira MF, Costa AM, Moritz GO, Bunn DA (Org.). Contribuições para a Gestão do SUS. Florianópolis: Fundação Boiteux; 2013.

15. Ciampone MHT, Peduzzi M. Trabalho em equipe e trabalho em grupo no programa de saúde da família. Rev Bras Enferm. 2000;53(spe):143-7.

16. Menezes KKP, Avelino PR. Grupos operativos na Atenção Primária à Saúde como prática de discussão e educação: uma revisão. Cad Saude Colet. 2016;24(1):124-30.

17. Brasil. Ministério da Saúde. Portaria n. 825, de 25 de abril de 2016. Redefine a Atenção Domiciliar no âmbito do Sistema Único de Saúde (SUS) e atualiza as equipes habilitadas. Brasília: Diário Oficial da União; 2016 Apr 26.

18. Lopes WDO, Saupe R, Massaroli A. Visita domiciliar: tecnologia para o cuidado, o ensino e a pesquisa. Cienc Cuid Saude. 2008;7(2):241-7.

19. Medeiros PA, Pivetta HMF, Mayer MS. Contribuições da visita domiciliar na formação em fisioterapia. Trab Educ Saude. 2012;10(3):407-26.

20. Trelha CS, Silva DW, Iida LM, Fortes MH, Mendes TS. O fisioterapeuta no Programa de Saúde da Família em Londrina (PR). Espaç Saude (Online). 2007;8(2):20-5.

21. Loures LF, Silva MCS. A interface entre o trabalho do agente comunitário de saúde e do fisioterapeuta na atenção básica à saúde. Cienc Saude Coletiva. 2010;15(4):2155-64.

22. Fonseca JMA. A Fisioterapia na Atenção Primária à Saúde: uma revisão integrativa. Rev Bras Promoc Saude. 2016;29(2):288-94. 
23. Brasil. Ministério da Saúde. Portaria Interministerial n. 3.696, de 25 de novembro de 2010. Estabelece critérios para adesão ao Programa Saúde na Escola (PSE) para o ano de 2010 e divulga a lista de Municípios aptos para Manifestação de Interesse. Brasília: Diário Oficial da União; 2010 Nov 26.

24. Vieira A, Treichel TL, Candotti CT, Noll M, Bartz PT. Efeitos de um Programa de Educação Postural para escolares do terceiro ano do Ensino Fundamental de uma escola estadual de Porto Alegre (RS). Fisioter Pesq. 2015;22(3):239-45.

25. Candotti CT, Nunes SEB, Noll M, Freitas K, Macedo CH. Efeitos de um programa de educação postural para crianças e adolescentes após oito meses de seu término. Rev Paul Pediatr. 2011;29(4):577-83.

26. Benini J, Karolczak APB. Benefícios de um programa de educação postural para alunos de uma escola municipal de Garibaldi, RS. Fisioter Pesq. 2010;17(4):346-51.

27. Sumiya A, Jeolás LS. Processos de mudança na formação do fisioterapeuta: as transições curriculares e seus desafios. Acta Scientiarum. Human and Social Sciences. 2009;32(1):47-53.

28. Peduzzi M, Norman IJ, Germani ACCG, Silva JAM, Souza GC. Educação interprofissional: formação de profissionais de saúde para o trabalho em equipe com foco nos usuários. Rev Esc Enferm USP. 2013;47(4):977-83.
29. Skupien JA, Wagner LC. Concepções Docentes sobre a formação em Fisioterapia. Cienc Mov. 2013;15(31):103-13.

30. Almeida SM, Martins AM, Escalda PMF. Integralidade e formação para o Sistema Único de Saúde na perspectiva de graduandos em Fisioterapia. Fisioter Pesq. 2014;21(3):271-8.

31. Matos E, Pires DEP, Campos GWS. Relações de trabalho em equipes interdisciplinares: contribuições para a constituição de novas formas de organização do trabalho em saúde. Rev Bras Enferm. 2009;62(6):863-9.

32. Teixeira ER, Veloso RC. 0 grupo em sala de espera: território de práticas e representações em saúde. Texto Contexto Enferm. 2006;15(2):320-5.

33. Santos DS, Andrade ALA, Lima BSS, Silva YN. Sala de espera para gestantes: uma estratégia de educação em saúde. Rev Bras Educ Med. 2012;36(1 Suppl 2):62-7.

34. Brasil. Ministério da Saúde. Núcleo de Apoio à Saúde da Família. Cadernos de Atenção Básica, n. 39. Brasília: Ministério da Saúde; 2014.

35. Castro SS, Silva YHG, Leite CF, Bollela VR. O processo saúde-doença e o modelo biopsicossocial entre supervisores de um curso de fisioterapia: estudo qualitativo em uma universidade pública. Cad Edu Saude e Fis. 2015;2(3):23-38.

Received: 10/19/2019

Recebido: 19/10/2019

Approved: 02/03/2020

Aprovado: 03/02/2020 